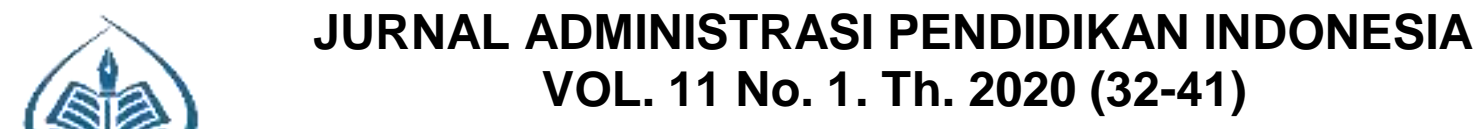

(Print ISSN 2613-9561 Online ISSN 2686-245X)

Tersedia online di http://ejournal-pasca.undiksha.ac.id/index.php/jurnal_ap

\title{
KONTRIBUSI KEPEMIMPINAN TRANSFORMASIONAL, BUDAYA ORGANISASI, DISIPLIN KERJA, DAN MOTIVASI KERJA, TERHADAP KOMITMEN ORGANISASIONAL GURU SD
}

Received: 23 Mei 2020; Revised: 8 Juli 2020; Accepted; 14 Juli 2020

Permalink/DOI: https://doi.org/10.23887/japi.v11i1.3167

\author{
S.M. Oupen ${ }^{1}$, A.A.G. Agung ${ }^{2}$, I.M. Yudana ${ }^{3}$ \\ 1,2,3 Program Studi Administrasi Pendidikan, Universitas Pendidikan Ganesha, Singaraja \\ email: stefimeilince@gmail.com ${ }^{1}$, agung2056@undiksha.ac.id², made.yudana@undiksha.ac.id ${ }^{3}$
}

\begin{abstract}
Abstrak
Penelitian ini bertujuan untuk mengetahui kontribusi kepemimpinan transformasional, budaya organisasi, disiplin kerja, dan motivasi kerja terhadap komitmen organisasional. Jenis penelitian ini adalah expost facto. Populasi penelitian ini adalah seluruh guru di SD Gugus III Kecamatan Buleleng yang berjumlah 153 orang. Dalam penelitian ini, sampel yang diambil menggunakan teknik proporsional random sampling, sebanyak 40 orang guru. Pengumpulan data menggunakan kuesioner kemudian dianalisis menggunakan analisis regresi sederhana dan analisis regresi ganda dengan bantuan aplikasi IBM Stastistic SPSS 23.0. Hasil penelitian menunjukkan bahwa: (1) terdapat kontribusi yang signifikan antara kepemimpinan transformasional terhadap komitmen organisasional dengan koefisien determinasi $29,26 \%$. (2) terdapat kontribusi yang signifikan budaya organisasi terhadap komitmen organisasional dengan koefisien determinasi $30,25 \%$. (3) terdapat kontribusi disiplin kerja terhadap komitmen organisasional dengan koefisien determinasi $16,56 \%$. (4) terdapat kontribusi motivasi kerja terhadap komitmen organisasional dengan koefisien determinasi $25,30 \%$. (5) Secara bersama-sama terdapat kontribusi yang signifikan kontribusi kepemimpinan transformasional, budaya organisasi, disiplin kerja, motivasi kerja terhadap komitmen organisasional dengan koefisien determinasi $53,66 \%$.
\end{abstract}

Kata kunci: Kepemimpinan Transformasional; Budaya Organisasi; Disiplin Kerja; Motivasi Kerja; Komitmen Organisasional.

\begin{abstract}
Abstrack
The purposes of this research was to know the contribution of transformational leadership, organizational culture, work discipline, work motivation, simultaneously to organizational commitment. The type of this research was expost facto. The target population for this research was the whole Elementary School III Group teachers Buleleng District of 153 respondents. The sample of this research was taken with proporsional random sampling technique, with total 40 teachers. The data collection using a questionnaire. The data analysis technique used simple regression analysis and multiple regression analysis with helped by using IBM Stastistic SPSS 23.0. The result showed that: (1) there is a significant influence transformational leadership to organizational commitment with determination coefficient $29.26 \%$. (2) there is a significant influence organizational culture to organizational commitment with determination coefficient $30.25 \%$. (3) there is an influence work discipline to organizational commitment with determination coefficient $16.56 \%$. (4) there is an influence work motivation to organizational commitment with determination coefficient $25.30 \%$. (5) there is an influence transformational leadership, organizational culture, work discipline, and work motivation simultaneously to organizational commitment with determination coefficient $53.66 \%$.
\end{abstract}

Keywords: Transformational Leadership; Organizational Culture; Work Discipline; Work Motivation; organizational Commitment. 


\section{PENDAHULUAN}

Sumber Daya Manusia adalah penduduk yang siap, mau dan mampu memberikan sumbangan terhadap usaha untuk mencapai tujuan organisasi. Siswa-siswi, guru, administrator, konselor, hidup bersama dan melaksanakan pendidikan secara teratur dan terencana dengan baik. Sekolah adalah lembaga pendidikan yang diselenggarakan dalam waktu yang sangat teratur, program yang sangat kaya dan sistematik, dilakukan oleh tenaga kependidikan yang profesional dalam bidangnya dan dilengkapi dengan fasilitas yang memadai. Berbicara masalah pendidikan tentunya tidak bisa lepas dari kualitas pendidik atau guru. Guru merupakan aktor utama dalam penyelenggaraan pendidikan. Undang-Undang Nomor 14 tahun 2005 tentang Guru dan Dosen pasal 1 menyatakan bahwa guru adalah pendidik profesional dengan tugas utama mendidik, mengajar, membimbing, mengarahkan, melatih, menilai, dan mengevaluasi peserta didik pada pendidikan anak usia dini jalur pendidikan formal, pendidikan dasar dan pendidikan menengah. Guru adalah sebuah profesi yang menuntut peleburan segala kemampuan dan waktu yang dimiliki. Guru dan dosen mempunyai fungsi, peran, dan kedudukan yang sangat strategis dalam pembangunan nasional dalam bidang pendidikan sehingga perlu dikembangkan sebagai profesi yang bermartabat. Menyadari pentingnya proses peningkatan mutu sumber daya manusia serta meningkatkan kualitas guru agar dapat melaksanakan sistem pendidikan nasional dan mewujudkan tujuan pendidikan nasional, maka pemerintah bersama kalangan swasta samasama telah dan terus berupaya mewujudkan amanat tersebut melalui berbagai usaha pembangunan pendidikan yang lebih bermutu antara lain melalui pengembangan dan perbaikan kurikulum dan sistem evaluasi, perbaikan sarana pendidikan, pengembangan dan pengadaan materi ajar, serta pemberian pendidikan dan pelatihan bagi guru. Namun kenyataannya upaya yang dilakukan belum maksimal untuk mencapai hasil yang diharapkan. Sekolah adalah tempat yang paling penting bagi anak untuk belajar dan mengembangkan pendidikan, sosial, kompetensi meningkatkan prestasi, dan memberikan pengalaman pendidikan yang berkualitas bagi semua siswa. Peraturan Pemerintah nomor 32 Tahun 2013 tentang Standar Nasional Pendidikan, menetapkan delapan Standar yang harus dipenuhi dalam melaksanakan pendidikan, kedelapan standar yang dimaksud meliputi: standar isi, standar proses, standar kompetensi lulusan, standar pendidik dan tenaga kependidikan, standar sarana dan prasarana, standar pengelolaan, standar pembiayaan dan standar penilaian pendidikan. Komitmen merupakan suatu keputusan seseorang dengan dirinya sendiri untuk melakukan suatu kegiatan tertentu agar tercapainya tujuan yang sudah disepakati. Komitmen guru dalam memberikan pengetahuan, tenaga serta pikiran kepada siswa adalah hal yang sangat penting guna mencapai tujuan pendidikan. Colquiit, LePine, dan Wesson (2009: 63) menggambarkan bahwa komitmen dipengaruhi oleh faktor-faktor yang meliputi: budaya organisasi (organizational culture), struktur organisasi (organizational structure), gaya dan perilaku kepemimpinan (leadership style and behavior), kekuatan dan pengaruh kepemimpinan (leadership power and influence), proses dan karakteristik tim (processes and characterisrics team), personal dan nilai budaya (personaity and cultural values), kemampuan (ability), sebagai faktor yang secara tidak langsung mempengaruhi pada komitmen. Faktor lain seperti kepuasan kerja (job satisfaction), stres (stress), motivasi (motivation), kepercayaan, keadilan, dan etika (trust, justice, and ethics), dan pengambilan keputusan (learning and decision making) sebagai faktor yang secara langsung mempengaruhi komitmen (dalam Turnip, dkk, 2018). Mengingat akan pentingnya hal tersebut, maka peranan seorang kepala sekolah dianggap penting karena bertindak sebagai pemimpin dalam merencanakan dan melaksanakan pembelajaran merupakan faktor utama dalam pencapaian keberhasilan disekolah. Secara harafiah dapat di interpretasikan sebagai pembimbing atau fasilisator bagi sekolah, disamping tugasnya bertanggungjawab dalam meningkatkan kualitas pelayanan pendidikan. Untuk mengetahui bagaimana komitmen guru, khususnya guru sekolah dasar dilakukan pengamatan di gugus III kecamatan buleleng kabupaten buleleng. Berdasarkan hasil wawancara yang dilakukan, terdapat beberapa informasi utama yang didapat tentang komitmen guru. Perjuangan mengenai komitmen guru, dimana komitmen afektif guru masih kurang baik yang dibuktikan dengan guru kurang disiplin, seperti datang masih tidak tepat waktu sesuai dengan ketentuan sekolah, banyak guru dalam 
mengajar masih menggunakan cara-cara tradisional dan belum sepenuhnya mengacu pada kurikulum dan kegiatan pembelajaran yang efektif dan efesien. Tanggung jawab sebagai seorang guru juga masih rendah karena belum semua guru menyiapkan RPP pada saat mengajar sehingga tujuan pembelajaran yang ingin dicapai kurang jelas. Serta kurangnya keterlibatan aktif para guru-guru dalam berbagai kegiatan dan kurangnya minat guru-guru untuk mengikuti berbagai seminar dan diklat yang diadakan secara bersama.

Hal senada juga ditemukan dari hasil observasi yang dilakukan, terdapat masalah yang berkaitan dengan pendidikan, yaitu masih rendahnya komitmen guru, ditemukan masalah pada komitmen guru yang masih kurang baik di sekolah. Adapun fenomena yang menunjukkannya antara lain: pertama, tanggung jawab kerja yang rendah, hal ini ditunjukkan dengan masih ada guru yang datang terlambat ke sekolah; kedua, guru belum sepenuhnya memberikan pelayanan yang terbaik kepada peserta didik, ditunjukkan dengan masih ada guru yang belum menyiapkan RPP, membuat media, dan jarang melakukan inovasi-inovasi dalam pembelajaran; ketiga guru belum terlibat aktif dalam kegiatan-kegiatan antar sekolah.

Salah satu faktor yang mempengaruhi komitmen kerja ialah kepemimpinan kepala sekolah. Makin efektif kepemimpinan seseorang, makin teguh komitmen bawahan atau sebaliknya. Kepemimpinan merupakan pengaruh interpersonal yang dilakukan dalam suatu situasi melalui proses komunikasi untuk mencapai tujuan atau sasaran tertentu. Maris (2016) menyatakan kepemimpinan transformasional kepala sekolah adalah kemampuan kepala sekolah dalam mentransformasikan pengaruhnya kepada seluruh warga sekolah secara efektif melalui idealize influence charismatik (karismatik), inspirational motivation (motivasi inspirasional), intellectual stimulation (stimulasi intelektual) dan individual consideration (perhatian terhadap individu) dalam mengembangkan dan meningkatkan profesionalismenya. instruksi, konsultasi, partisipasi, dan delegasi yang dilakukan kepala sekolah terhadap bawahan yang juga termasuk perilaku kepemimpinan kepala sekolah sangat mempengaruhi komitmen kerja guru. Oleh karena itu, untuk meningkatkan komitmen kerja guru, maka kepala sekolah perlu memperhatikan cara kepemimpinannya, bagaimana berperilaku terhadap bawahan dalam kondisi tertentu, komunikasi dua arah dengan bawahan, dan melakukan delegasi kepada bawahan.

Budaya sebuah organisasi juga mempengaruhi komitmen kerja guru. Budaya organisasi itu berkaitan dengan cara karyawan mempersepsikan karakteristik budaya organisasi, bukannya dengan apakah mereka menyukai budaya itu atau tidak. Artinya, budaya itu merupakan istilah deskriplif. Pemahaman.ini penting karena membedakan konsep budaya dari konsep kepuasan kerja. Riset mengenai budaya organisasi telah berupaya mengukur bagaimana karyawan memandang organisasinya: Apakah organisasi itu mendorong kerja tim? Apakah organisasi itu menghargai inovasi? Apakah melumpuhkan prakarsa?. Riset paling baru mengemukakan tujuh karakteristilk primer berikut yang bersama-sama, menangkap hakikat dari budaya organisasi. Pertama, inovasi dan pengambilan risiko. Sejauh mana para karyawan didorong agar inovatif dan mengambil risiko. Kedua, perhatian terhadap detail. Sejauh mana para karyawan diharapkan memperlihatkan presisi (kecermatan), analisis, dan perhatian terhadap detail. Ketiga, orientasi hasil. Sejauh mana manajemen memusatkan perhatian pada hasil bukannya pada teknik dan proses yang digunakan untuk mencapai hasil itu. Keempat, orientasi orang. Sejauh mana keputusan manajemen memperhitungkan dampak hasil-hasil pada orang-orang di dalam organisasi itu. Kelima, orientasi tim. Sejauh mana kegiatan kerja diorgarisasikan berdasar tim, bukannya berdasar individu. Keenam, kengresifan. Sejauh mana orang-orang itu agresif dan kompetitif dan bukannya santai-santai. Ketujuh, kemantapan. Sejauh status kegiatan organisasi menekankan dipertahankannya status quo bukannya pertumbuhan. Dimensi-dimensi yang dilakukan organisasi tersebut misalnya perilaku pemimpin dalam memberikan contoh dalam hal bertanggungjawab atas tugas yang diberikan, dan juga menjadi teladan bagi bawahannya. Spiritualitas, ketekunan, ketulusan, kepercayaan terhadap bawahan, jika itu merupakan budaya organisasi tersebut maka sangat berpengaruh baik terhadap komitmen kerja guru.

Disiplin dapat diartikan sebagai sikap seseorang atau kelompok yang berniat untuk mengikuti aturan-aturan yang telah ditetapkan. Disiplin kerja dapat diartikan sebagai sikap seseorang atau kelompok yang berniat untuk mengikuti aturan-aturan yang telah ditetapkan (Yuspratiwi dalam 
Helmi, 1996). Dalam kaitannya dengan pekerjaan, pengertian disiplin kerja adalah suatu sikap dan tingkah laku yang menunjukkan ketaatan karyawan terhadap peraturan organisasi. Menurut Lateiner (dalam Indriyati, 2017) indikator disiplin kerja terdiri atas: (1) ketepatan waktu. Jika karyawan datang ke kantor tepat waktu, pulang kantor tepat waktu, serta karyawan dapat bersikap tertib maka dapat dikatakan karyawan tersebut memiliki displin kerja yang baik. (2), pemanfaatan sarana. Karyawan yang berhati-hati dalam menggunakan peralatan kantor untuk menghindari terjadinya kerusakan pada alat kantor merupakan cerminan karyawan yang memiliki disiplin kerja yang baik. (3), tanggung jawab yang tinggi. Karyawan yang selalu menyelesaikan tugas yang dibebankan kepadanya sesuai dengan prosedur dan bertanggung jawab terhadap hasil kerjanya, dapat pula dikatakan memiliki disiplin kerja yang tinggi. (4), ketaatan terhadap aturan kantor. Karyawan yang memakai seragam sesuai aturan, mengenakan kartu tanda identitas, ijin apabila tidak masuk kantor, juga merupakan cerminan disiplin yang tinggi. Dalam kaitannya dengan pekerjaan, pengertian disiplin kerja adalah suatu sikap dan tingkah laku yang menunjukkan ketaatan karyawan terhadap peraturan organisasi. Disiplin kerja juga bisa dilihat melalui ketepatan waktu, pemanfaatan sarana, tanggung jawab bawahan, ketaatan terhadap aturan organisasi. Motivasi kerja seseorang juga mempengaruhi komitmen kerjanya. Apakah organisasi tersebut memenuhi kepuasan kerja bawahan sehingga bawahan semakin berkomitmen untuk bekerja pada organisasi tersebut. Yang menjadi motivasi bawahan ialah pengharapan, penghargaan, prestasi, hubungan kerja, pengembangan diri, administrasi dan kebijakan pimpinan, jika terpenuhi maka komitmen kerja guru juga semakin meningkat bahkan sebaliknya.

Komitmen kerja organisasi adalah kondisi keberadaan karyawan berkomitmen untuk membantu dalam pencapaian tujuan organisasi, dan melibatkan tingkat identifikasi, keterlibatan,dan kesetiaan (Caught \& Shadur, 2000). Itu adalah respons emosional yang dapat diukur melalui perilaku, keyakinan, dan sikap dan dapat berkisar dari sangat rendah hingga sangat tinggi. John Meyer dan Nancy Allen (1997) telah mengidentifikasi tiga jenis komitmen organisasi: afektif, kelanjutan, dan normatif. Pertama, Komitmen afektif atau moral. terjadi ketika individu sepenuhnya merangkul tujuan dan nilai-nilai organisasi. Mereka menjadi terlibat secara emosional dengan organisasi dan merasa bertanggung jawab secara pribadi untuk tingkat organisasi kesuksesan. Orang-orang ini biasanya menunjukkan tinggi tingkat kinerja, sikap kerja positif, dan keinginan untuk tetap bersama organisasi. Kedua, kelanjutan atau komitmen kalkulatif. terjadi ketika individu mendasarkan hubungan mereka dengan organisasi apa yang mereka terima sebagai imbalan atas upaya mereka dan apa akan hilang jika mereka pergi (mis., membayar, tunjangan,asosiasi). Orang-orang ini melakukan upaya terbaik mereka hanya saat penghargaan sesuai dengan harapan mereka. Ketiga, komitmen normatif. terjadi ketika individu tetap dengan organisasi berdasarkan standar yang diharapkan dari perilaku atau norma sosial. Nilai-nilai individu ini kepatuhan, kewaspadaan, dan formalitas. Saran penelitian bahwa mereka cenderung menampilkan sikap dan perilaku yang sama mereka yang memiliki komitmen afektif. Komitmen yang baik ditunjukkan oleh guru berkaitan dengan motivasi kerja dan prestasi yang dimiliki oleh anak didiknya. Dengan meningkatnya kinerja yang baik, maka guru dapat memainkan perannya sebagai subjek pembangunan nasional dengan baik dimana tujuan tersebut tersirat dalam visi dan misi sekolah. Kebanggan seorang guru akan menghasilkan komitmen guru untuk terus berjuang memperbaiki dan memajukan dunia pendidikan melalui proses belajar dan mengajar yang berkualitas.

Motivasi seorang guru juga sangat berpengaruh pada komitmen kerja guru tersebut. Heller (dalam Wibowo, 2012) yang menyatakan bahwa motivasi adalah keinginan untuk bertindak. Ada pendapat bahwa motivasi harus diinjeksi dari luar, tetapi sekarang semakin dipahami bahwa setiap orang termotivasi oleh beberapa kekuatan yang berbeda. Di pekerjaan kita perlu memengaruhi bawahan untuk menyelaraskan motivasinya dengan kebutuhan organisasi. Teori motivasi yang paling terkenal adalah hierarki kebutuhan yang diungkapkan Abraham Maslow. Hipotesisnya mengatakan bahwa, di dalam diri semua manusia bersemayam lima jenjang kebutuhan, yaitu sebagai berikut. Pertama, psikologis: antara lain rasa lapar, haus, perlindungan (pakaian dan perumahan), seks, dan kebutuhan jasmani lain. Kedua, keamanan: antara lain keselamatan dan perlindungan terhadap kerugian fisik dan emosional. Ketiga, sosial: mencakup kasih sayang, rasa memiliki, diterima-baik, dan 
persahabatan. Keempat, penghargaan: mencakup faktor penghormatan diri seperti harga diri, otonomi, dan prestasi; serta faktor penghormatan dari luar seperti misalnya status, pengakuan, dan perhatian. Kelima, aktualisasi diri: dorongan untuk menjadi seseorang/sesuatu sesuai ambisinya yang mencakup pertumbuhan, pencapaian potensi, dan pemenuhan kebutuhan diri.

Dalam penelitian ini juga ditemukan kajian hasil penelitian yang relevan sebagai berikut. Pertama, Penelitian yang dilakukan Edi Purnomo (2017). Hasil penelitiannya dinyatakan bahwa ada pengaruh kepemimpinan kepala sekolah, budaya kerja, komitmen, terhadap keunggulan sekolah dan disarankan agar hasil penelitian ini dijadikan bahan referensi dalam upaya menyusun berbagai kebijakan untuk mewujudkan keunggulan sekolah. Kedua, penelitian yang dilakukan Cut Nurviza, Yusrizal, dan Nasir Usman (2019). Dalam penelitiannya dinyatakan bahwa terdapat pengaruh yang siginfikan antara budaya organisasi dan kepemimpinan kepala sekolah terhadap kinerja guru yaitu sebesar. Kinerja guru akan meningkat seiring adanya kondisi hubungan dan komunikasi yang sehat di antara komponen sekolah sebab dengan pola hubungan dan komunikasi yang lancar dan baik mendorong pribadi seseorang untuk melakukan tugas dengan baik. Ketiga, penelitian yang dilakukan oleh Amelia Rahmi dan Mulyadi (2018). Dalam penelitiannya dinyatakan bahwa secara uji serempak antara variabel keterlibatan karyawan, budaya organisasi dan kepemimpinan transformasional berpengaruh signifikan terhadap komitmen organisasional. Secara parsial yaitu variabel budaya organisasi dan kepemimpinan transformasional berpengaruh signifikan terhadap komitmen organisasional.

"Berdasarkan latar belakang masalah tersebut, maka penelitian ini bertujuan untuk mengetahui kontribusi kepemimpinan transformasional, budaya organisasi, disiplin kerja, dan motivasi kerja, terhadap komitmen organisasional Guru SD Tahun 2020”.

\section{METODE}

Jenis penelitian ini adalah expost facto. Populasi dalam penelitian ini adalah seluruh guru di SD Gugus III Kecamatan Buleleng yang berjumlah 153 orang. Dalam penelitian ini, sampel yang diambil menggunakan teknik proposional random sampling, sebanyak 40 orang guru. Variabel terikat dalam penelitian ini adalah komitmen organisasional, sedangkan variabel bebasnya adalah kepemimpinan transformasional, budaya organisasi, disiplin kerja, dan motivasi kerja.

Data dikumpulkan melalui pengumpulan kuesioner dan kemudian dianalisis menggunakan analisis regresi sederhana dan analisis regresi ganda dengan bantuan aplikasi IBM Stastistic SPSS 23.0. Data hasil penelitian juga dianalisis menggunakan teknik analisis statistik deskriptif dan disajikan kedalam: Mean (M), Median (Me), Modus (Mo). Selanjutnya dianalisis menggunakan teknik analisis statistik inferensial menggunakan uji normalitas, uji linieritas, uji multikolinieritas, uji autokorelasi, uji heterokedastisitas. Kemudian dianalisis menggunakan analisis regresi dengan pengujian Hipotesis Pertama, Kedua, Ketiga dan Keempat serta pengujian Hipotesis Kelima.

\section{HASIL DAN PEMBAHASAN \\ Hipotesis 1. Hubungan antara Kepemimpinan Transformasional dengan Komitmen Organisasional}

Dari analisis yang telah dilakukan, diperoleh nilai koefisien korelasi antara kepemimpinan transformasional terhadap komitmen organisasional sebesar 0,541 dengan koefisien determinasi sebesar $29,26 \%$. Hal ini menunjukkan terdapat hubungan antara kepemimpinan transformasional terhadap komitmen organisasional yang berada pada kategori cukup kuat dengan kontribusi sebesar $29,26 \%$.

Hasil analisis yang menyatakan terdapat hubungan yang positif antara kepemimpinan transformasional terhadap komitmen organisasional ini juga didukung oleh penelitian yang dilakukan Cut Nurviza, Yusrizal, dan Nasir Usman (2019) yang menyatakan terdapat pengaruh signifikan antara kepemimpinan kepala sekolah terhadap kinerja guru yaitu sebesar $11,70 \%$. Artinya kepemimpinan kepala sekolah berpengaruh terhadap kinerja guru yang secara umum dapat dikemukakan bahwa keterampilan yang dimiliki oleh kepala sekolah meliputi 
keterampilan konseptual, keterampilan hubungan dengan bawahannya dan keterampilan serta adanya sikap dan perilaku kepemimpinan yang kondusif sangat berpengaruh terhadap kinerja guru.

Kepemimpinan merupakan pengaruh interpersonal yang dilakukan dalam suatu situasi melalui proses komunikasi untuk mencapai tujuan atau sasaran tertentu. Maris (2016) menyatakan kepemimpinan transformasional kepala sekolah adalah kemampuan kepala sekolah dalam mentransformasikan pengaruhnya kepada seluruh warga sekolah secara efektif melalui idealize influence charismatik (karismatik), inspirational motivation (motivasi inspirasional), intellectual stimulation (stimulasi intelektual) dan individual consideration (perhatian terhadap individu) dalam mengembangkan dan meningkatkan profesionalismenya.

Komitmen kerja guru akan meningkat seiring adanya kondisi hubungan dan komunikasi yang sehat diantara komponen sekolah termasuk kepala sekolah. Makin efektif kepemimpinan seorang kepala sekolah, makin teguh komitmen guru atau sebaliknya. Hal ini diperkuat dengan pendapat Nelda (2016) yang menyatakan bahwa guru akan memiliki komitmen terhadap organisasi dalam melakukan pekerjaannya apabila ditunjang oleh kepemimpinan kepala sekolah yang baik yaitu pemimpinan kepala sekolah yang mampu mempengaruhi, memotivasi dan memperlakukan guru secara profesional serta mampu menginspirasi guru-guru, sehingga guru dalam melaksanakan tugas-tugasnya lebih bertanggung jawab, dan bersedia mengusahakan yang terbaik bagi organisasi, dan pada akhirnya dapat menumbuhkan komitmen yang tinggi di kalangan guru. Oleh karena itu, kepala sekolah perlu memperhatikan cara kepemimpinannya, bagaimana berperilaku terhadap bawahan dalam kondisi tertentu, komunikasi dua arah dengan bawahan, dan melakukan delegasi kepada bawahan untuk lebih meningkatkan komitmen guru.

\section{Hipotesis 2. Hubungan antara Budaya Organisasi dengan Komitmen Organisasional}

Dari analisis yang telah dilakukan, diperoleh nilai koefisien korelasi antara budaya organisasi dengan komitmen organisasional sebesar 0,550 dengan koefisien determinasi sebesar $30,25 \%$. Hal ini menunjukkan terdapat hubungan antara budaya organisasi terhadap komitmen organisasional yang berada pada kategori cukup kuat dengan kontribusi sebesar $30,25 \%$.

Hasil analisis yang menyatakan terdapat hubungan yang positif antara budaya organisasi terhadap komitmen organisasional ini juga didukung oleh penelitian yang dilakukan Cut Nurviza, Yusrizal, dan Nasir Usman (2019) yang menyatakan terdapat pengaruh yang signifikan antara budaya organisasi terhadap kinerja guru yaitu sebesar $13,54 \%$. Artinya bahwa keberhasilan pelaksanaan budaya organisasi dapat dilihat dari peningkatan tanggung jawab, peningkatan kedisiplinan dan kepatuhan terhadap norma-norma dan kebiasaan.

Greenberg dan Baron (1995) menyatakan salah satu fungsi budaya organisasi adalah meningkatkan komitmen karyawan atau anggota terhadap misi organisasi. Robbins (1996) juga memaparkan salah satu gungsi budaya organisasi adalah mempermudah munculnya komitmen dalam diri individu, dimana komitmen tersebut menjadi lebih penting dibanding kepentingan diri individu. Mencermati pendidikan sebagai suatu sistem, maka komitmen guru tidak terlepas dari budaya organisasi. Budaya organisasi sekolah atau dimensi-dimensi yang dilakukan organisasi seperti perilaku pemimpin dalam memberikan contoh dalam hal bertanggungjawab atas tugas yang diberikan dan menjadi teladan bagi bawahannya, spiritualitas, ketekunan, ketulusan, kepercayaan terhadap bawahan, sangat berpengaruh baik terhadap komitmen kerja guru. Semakin kondusif budaya organisasi sekolah maka komitmen guru juga semakin tinggi. Sebaliknya, budaya organisasi sekolah yang kurang kondusif, tidak memungkinkan terjadinya perubahan-perubahan dan tidak diterapkannya nilai-nilai spiritualitas, kepercayaan, ketulusan, ketekutan, dan kebersamaan akan kurang dapat menumbuhkan komitmen guru. Hal ini diperkuat dengan pendapat Juwita (2016) yang menyatakan budaya sekolah merupakan salah satu faktor dalam kinerja guru. Budaya organisasi sekolah yang kondusif akan menjadi media untuk meningkatkan kinerja guru.

Hasil penelitian ini juga sejalan dengan temuan penelitian yang dilakukan oleh Megawati (2013) yakni, budaya organisasi sekolah membuat guru mencintai pekerjaan dan para siswa yang dibelajarkan sehingga tumbuh komitmen afektif terhadap pekerjaan guru. Komitmen 
inilah yang membuat guru enggan mencari pekerjaan lain meskipun guru memiliki kemampuan dan latar belakang pendidikan yang tinggi. Dengan demikian, Semakin kondusif budaya organisasi sekolah maka semakin meningkat komitmen yang dimiliki guru baik komitmen afektif, normatif, maupun kontinuans.

\section{Hipotesis 3. Hubungan antara Disiplin Kerja dengan Komitmen Organisasional}

Dari analisis yang telah dilakukan, diperoleh nilai koefisien korelasi antara disiplin kerja dengan komitmen organisasional sebesar 0,407 dengan koefisien determinasi sebesar $16,56 \%$. Hal ini menunjukkan terdapat hubungan antara disiplin kerja terhadap komitmen organisasional yang berada pada kategori cukup kuat dengan kontribusi sebesar $16,56 \%$.

Hasil analisis yang menyatakan terdapat hubungan yang positif antara disiplin kerja terhadap komitmen organisasional ini juga didukung oleh penelitian yang dilakukan Purwoko (2018) yang menyatakan terdapat pengaruh positif dan signifikan disiplin guru terhadap kinerja guru sebesar $21,62 \%$. Disiplin dapat diartikan sebagai sikap seseorang atau kelompok yang berniat untuk mengikuti aturan-aturan yang telah ditetapkan. Dalam kaitannya dengan pekerjaan, disiplin kerja adalah suatu sikap dan tingkah laku yang menunjukkan ketaatan karyawan terhadap peraturan organisasi. Dengan adanya disiplin kerja yang tinggi, guru tidak perlu lagi diawasi setiap saat untuk melakukan pekerjaan dengan baik sebab ia pasti akan selalu melakukan pekerjaan sebaik mungkin dan selalu mematuhi aturan-aturan yang telah disepakati. Hal ini juga diperkuat dengan hasil penelitian yang dilakukan oleh Liana (2014) yang menyatakan disiplin kerja berkontribusi secara signifikan terhadap komitmen organisasi.

Gouzali (Sudjana, 2004) yang menyatakan bahwa komitmen kerja merupakan faktor yang ikut mempengaruhi disiplin kerja seorang karyawan (guru). Gouzali menegaskan bahwa pekerja yang memiliki komitmen yang baik akan tergambar dari tingginya disiplin, semangat dan gairah kerja mereka dalam melakukan pekerjaan. Dengan demikian, disiplin kerja guru yang tinggi berdampak terhadap komitmen yang dimiliki guru juga tinggi.

\section{Hipotesis 4. Hubungan antara Motivasi Kerja dengan Komitmen organisasional}

Dari analisis yang telah dilakukan, diperoleh nilai koefisien korelasi antara motivasi kerja dengan komitmen organisasional sebesar 0,503 dengan koefisien determinasi sebesar $25,30 \%$. Hal ini menunjukkan terdapat hubungan antara motivasi kerja terhadap komitmen organisasional yang berada pada kategori cukup kuat dengan kontribusi sebesar $25,30 \%$.

Hasil analisis yang menyatakan terdapat hubungan yang positif antara motivasi kerja terhadap komitmen organisasional ini juga didukung oleh penelitian yang dilakukan Liana (2014) yang menyatakan motivasi berpengaruh signifikan terhadap komitmen organisasi sebesar $47,7 \%$. Motivasi kerja seseorang juga mempengaruhi komitmen kerjanya. Robert Heller (1998: 6 dalam Wibowo, 2012) yang menyatakan bahwa motivasi adalah keinginan untuk bertindak. Motivasi mampu mendorong seseorang untuk melaksanakan pekerjaan dengan keteguhan hati dan memiliki pengorbanan dalam bekerja, sehingga motivasi yang tinggi akan menciptakan sebuah komitmen terhadap apa yang menjadi tanggung jawabnya dalam menyelesaikan setiap pekerjaan.

Harsey dalam Musparni (2011:25) menyatakan faktor motivasi kerja menjadi daya gerak yang mencakup dorongan, alasan dan kemauan yang timbul dalam diri untuk berbuat sesuatu, misalnya seorang pegawai (guru) menerima penghargaan yang diterima berupa gaji atau imbalan yang sesuai, maka komitmen organisasionalnya akan semakin meningkat. Dengan demikian komitmen organisasional akan semakin meningkat dengan adanya motivasi yang semakin tinggi.

\section{Hipotesis 5. Hubungan antara Kepemimpinan Transformasional, Budaya Organisasi, Disiplin Kerja, dan Motivasi Kerja dengan Komitmen Organisasional}

Dari analisis yang telah dilakukan, diperoleh nilai koefisien korelasi antara kepemimpinan transformasional, budaya organisasi, disiplin kerja, dan motivasi kerja terhadap komitmen organisasional sebesar 0,735 dengan koefisien determinasi sebesar $53,66 \%$. Hal ini menunjukkan terdapat hubungan antara kepemimpinan transformasional, budaya organisasi, disiplin kerja, dan motivasi kerja terhadap komitmen organisasional yang berada pada kategori 
kuat dengan kontribusi sebesar $53,66 \%$. Dengan demikian, penelitian ini tidak hanya mengungkapkan bahwa terdapat kontribusi kepemimpinan transformasional, budaya organisasi, disiplin kerja, dan motivasi kerja terhadap komitmen organisasional secara parsial tetapi juga secara simultan.

Hasil penelitian ini juga didukung oleh hasil penelitian yang dilakukan Cut Nurviza, Yusrizal, dan Nasir Usman (2019) yang menyatakan terdapat pengaruh yang siginfikan antara budaya organisasi dan kepemimpinan kepala sekolah terhadap kinerja guru yaitu sebesar $20,70 \%$. Sejalan dengan hal ini, uji serempak yang dilakukan Rahmi dan Mulyadi (2018) juga memberikan hasil bahwa keterlibatan karyawan, budaya organisasi dan kepemimpinan transformasional pada PT. PLN Banda Aceh berpengaruh signifikan terhadap komitmen organisasional pada PT. PLN Banda Aceh.

Kepemimpinan transformasional, budaya organisasi, disiplin dan motivasi kerja akan menjanjikan terciptanya suasana sekolah yang kondusif dan tenang yang dapat meningkatkan komitmen organisasional. Kepala sekolah sebagai pimpinan di sekolah memiliki peran yang strategis dalam meningkatkan komitmen guru dengan mempengaruhi, memotivasi dan memperlakukan guru secara profesional serta mampu menginspirasi guru-guru sehingga dalam melaksanakan tugas-tugasnya, guru lebih bertanggung jawab, dan bersedia mengusahakan yang terbaik bagi organisasi. Selain itu, budaya organisasi sekolah atau dimensi-dimensi yang dilakukan organisasi seperti perilaku pemimpin dalam memberikan contoh dalam hal bertanggungjawab atas tugas yang diberikan dan menjadi teladan bagi bawahannya, spiritualitas, ketekunan, ketulusan, kepercayaan terhadap bawahan, sangat berpengaruh baik terhadap komitmen kerja guru. Sekolah yang memiliki budaya organisasi yang kondusif dapat menumbuhkan komitmen guru baik afektif, normatif, maupun kontinuans.

Disamping itu, disiplin kerja dan motivasi kerja turut andil dalam menumbuhkan komitmen organisasional. Didiplin dan motivasi yang tinggi akan menciptakan sebuah komitmen yang tinggi terhadap apa yang menjadi tanggung jawab guru dalam dalam menyelesaikan setiap pekerjaan. Adanya keterikatan tingkat emosional yang tinggi antara warga sekolah dan adanya kepuasan terhadap penghargaan yang diterima maka guru memiliki kesadaran untuk selalu hadir tepat waktu, menjalankan tugas dengan sebaik mungkin dan dengan penuh tanggung jawab. Dengan demikian, adanya kepemimpinan transformasional kepala sekolah yang baik, budaya aorganisasi yang kondusif, disiplin dan motivasi kerja yang tinggi dapat meningkatkan komitmen kerja yang dimiliki oleh guru.

\section{SIMPULAN}

Berdasarkan rumusan masalah dan hasil penelitian, maka simpulan dalam penelitian ini adalah sebagai berikut. (1) terdapat kontribusi yang signifikan kepemimpinan transformasional terhadap komitmen organisasional dengan koefisien determinasi $29,26 \%$. (2) terdapat kontribusi yang signifikan budaya organisasi terhadap komitmen organisasional dengan koefisien determinasi 30,25\%. (3) terdapat kontribusi yang signifikan disiplin kerja terhadap komitmen organisasional dengan koefisien determinasi 16,56\%. (4) terdapat kontribusi yang signifikan motivasi kerja terhadap komitmen organisasional dengan koefisien determinasi $25,30 \%$. (5) terdapat kontribusi yang signifikan kepemimpinan transformasional, budaya organisasi, dan motivasi kerja, terhadap komitmen organisasional dengan koefisien determinasi $53,66 \%$.

\section{DAFTAR PUSTAKA}

Agung, A. A. G. 2014. Metodologi Penelitian Pendidikan. Malang: Aditya Media Publishing.

Agung, A. A. G. 2017. Statistika Inferensial untuk Pendidikan. Universitas Pendidikan Ganesha.

Allen \& Meyer. 1997. Commitment In The Workplace (Theory, Research and Application). Sage Publication London. 
Caught, K, Shadur, M. A, \& Rodwell, J. J. (2000). The measurement artifact in the organizational commitment questionnaire. Psychological Reports, Vol.87 (3), 777-788.

Dantes, Nyoman. 2012. Metode Penelitian. Yogyakarta: CV Andi Offset.

Departemen Pendidikan Nasional, 2013. Peraturan Pemerintah Nomor 32 Tahun 2013 tentang Standar Nasional Pendidikan. Jakarta: Depdiknas.

Departemen Pendidikan Nasional, 2005. Undang-Undang Nomor 14 Tahun 2005 Tentang Guru dan Dosen. Jakarta: Depdiknas.

Greenber, Jerald dan Robert A Baron. 1995. Behavior in Organizations Understanding and Managing The Human Side of Work. Edisi 5. US: Prentice-Hall

Helmi, A. F. 1996. Disiplin Kerja. Buletin Psikologi, Volume 4 Nomor 2.

Indriyati Endah Susetyo. 2017. Pengaruh Gaya Kepemimpinan, Motivasi dan Disiplin Kerja terhadap Kinerja Karyawan dengan Pemahaman Etika Kerja Islami. Upajiwa Dewantara Vol. 1 No. 2.

Juwita, marni. 2016. Pengaruh Budaya Organisasi, Komitmen Guru dan Motivasi Kerja Terhadap Kinerja Guru SMPN 3 Mukomuko. Skripsi.197 halaman. Diakses tanggal 26 April 2020.

Koyan, I. W. 2012. Statistik Teknik Analisis Data Kuantitatif. Singaraja: Universitas Pendidikan Ganesha Press.

Liana, Yuyuk dan Rina Irawati. 2014. "Peran Motivasi, Disiplin Kerja Terhadap Komitmen Karyawan dan Kinerja Karyawan Pada Perusahaan Air Minum di Malang Raya". Jurnal Manajemen dan Akuntansi. 3(1). Hal 17-34

Maris, Intan Silvana dkk. 2016. "Kepemimpinan Transformasional Kepala Seolah, Kinerja Guru dan Mutu Sekolah". Jurnal Administrasi Pendidikan. 23 (2). Hal 173-188

Megawati, Priarti. 2013. "Hubungann Budaya Organisasi dan Kepuasan Kerja dengan Komitmen Organisasi Guru Honorer". Jurnal Formatif. 3(1). Hal 26-38.

Musparini. 2011. Pengaruh Supervisi Pimpinan, Iklim Kerja dan Motivasi Kerja Terhadap Komitmen Kerja Karyawan Pangeran's Beach Hotel Padang. Tesis. Padang. UNP. Diakses tanggal 26 April 2020

Nelda, Fitri. 2016. "Hubungan Kepemimpinan Kepala Sekolah dengan Komitmen Guru dalam Melaksanakan Tugas di SMKN 2 Pariaman”. Jurnal administrasi Pendidikan. 1(29). Hal $1-8$

Nurviza. 2019. Pengaruh Budaya Organisasi dan Kepemimpinan Kepala Sekolah terhadap Kinerja Guru pada SMA Unggul Negeri 2 Boarding School Kota Banda Aceh. Jurnal Magister Administrasi Pendidikan, Vol 7, No.1.

Purnomo Edi. 2017. Pengaruh Kepemimpinan Kepala Sekolah, Budaya Kerja, dan Komitmen terhadap Keunggulan Sekolah (Studi pada SMP Negeri 2 Jombang). Jurnal IImu Manajemen, Vol 06, No. 4.

Purwoko, Sidik. 2018. "Pengaruh Kepemimpinan Kepala Sekolah, Komitmen Guru, Disiplin Kerja Guru, dan Budaya Sekolah Terhadap Kinerja Guru SMK". Jurnal Akuntabilitas Manajemen Pendidikan. 6(2). Hal 149-162. 
Rahmi dan Mulyadi. 2018. Pengaruh Keterlibatan Karyawan, Budaya Organisasi dan Kepemimpinan Transformasional terhadap Komitmen Organisasional Karyawan pada PT. PLN Banda Aceh. Jurnal IIman, Vol. 6, No. 1.

Robbins, Stephen P. 1996. Perilaku Organisasi Jilid 2, Konsep, Kontroversi, Aplikasi. Jakarta: Prenhallindo.

Sudjana, Nana. 2004. Tuntunan penyusunan Karya IImiah. Bandung: Sinar Baru Algesindo

Turnip, dkk. 2018. Pengaruh Kecerdasan Emosional, Persepsi Guru tentang Komunikasi Interpersonal Kepala Sekolah, dan Kompensasi terhadap Komitmen Afektif Guru TK Kecamatan Medan Perjuangan. Jurnal Usia Dini, Volume 4 No. 2.

Wahyosumidjo. 2007. Kepemimpinan Kepala Sekolah. Jakarta: PT RajaGrafindo Persada.

Wibowo. 2012. Manajemen Kinerja. Jakarta: PT RajaGrafindo Persada. 